\title{
THE QMRACATCH APPROACH FOR GUIDING SUSTAINABLE WATER SAFETY MANAGEMENT OPTIONS AT A LARGE RIVER
}

\author{
Julia Derx \\ Institute of Hydraulic Engineering and Water Resources Management, TU Wien \\ Vienna, Austria \\ Jack Schijven \\ National Institute for Public Health and the Environment \\ Bilthoven, Netherlands
}

\section{Regina Sommer}

Institute for Hygiene and Applied Immunology, Water Hygiene, Medical University of Vienna Vienna, Austria

\section{Christa M. Zoufal-Hruza}

Municipal Department 39, Laboratories for Environmental Medicine, IFUM

Vienna, Austria

\section{Rita Linke}

Research Group of Environmental Microbiology and Molecular Diagnostics, Institute of Chemical, Environmental and Bioscience Engineering, TU Wien

Vienna, Austria

\section{Alfred P. Blaschke}

Institute of Hydraulic Engineering and Water Resources Management, TU Wien

Vienna, Austria

\section{Andreas Farnleitner}

Institute of Chemical, Environmental and Bioscience Engineering, TU Wien

Karl Landsteiner University of Health Science, Department for Water Quality and Health

Vienna, Austria 


\section{Copyright:}

\section{cc) (1) (2) \\ BY SA}

This publication is available in Open Access under the Attribution-ShareAlike 3.0 IGO (CC-BY-SA 3.0 IGO) license (http://creativecommons.org/licenses/by-sa/3.0/igo). By using the content of this publication, the users accept to be bound by the terms of use of the UNESCO Open Access Repository (http://www.unesco.org/openaccess/terms-use-ccbysa-en).

\section{Disclaimer:}

The designations employed and the presentation of material throughout this publication do not imply the expression of any opinion whatsoever on the part of UNESCO concerning the legal status of any country, territory, city or area or of its authorities, or concerning the delimitation of its frontiers or boundaries. The ideas and opinions expressed in this publication are those of the authors; they are not necessarily those of UNESCO and do not commit the Organization.

\section{Citation:}

Derx, J., Schijven, J., Sommer, R., Zoufal-Hruza, C.M., Linke, R., Blaschke, A.P. and Farnleitner, A. (2019). The QMRAcatch approach for guiding sustainable water safety management options at a large river. In: J.B. Rose and B. Jiménez-Cisneros, (eds) Water and Sanitation for the 21st Century: Health and Microbiological Aspects of Excreta and Wastewater Management (Global Water Pathogen Project). (S. Petterson and G. Medema (eds) Part 5: Case Studies), Michigan State University, E. Lansing, MI, UNESCO.

https://doi.org/10.14321/waterpathogens.78

Acknowledgements: K.R.L. Young, Project Design editor; Website Design: Agroknow (http://www.agroknow.com)

Last published: March 11, 2019 


\section{Summary}

\section{Highlights}

* The QMRAcatch model to support microbial water safety management at urban RBF settings.

* Catchment-specific model calibration and verification with microbial source tracking data.
* Integrate QMRA with hydrological process modelling and pathogen emission scenarios.

* Identified sustainable requirements for safe drinking water production (SDG goal 6).

* Applicable for WSP but similarly for SSP, e.g., for irrigation from sewage polluted waters.

\section{Graphical abstract}

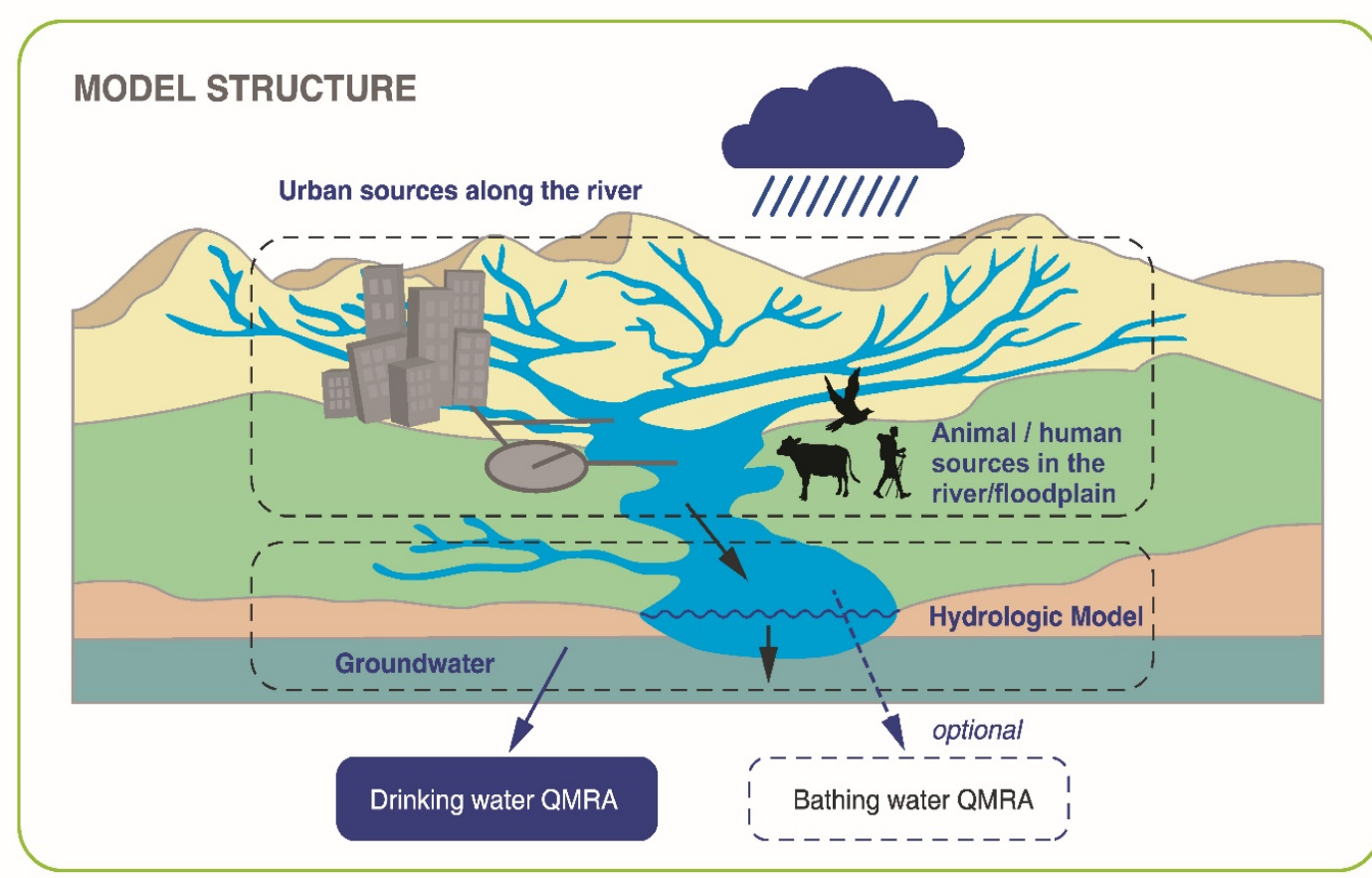

\section{WORKFLOW}

Step 1 Calibration using MST markers

Step 2 Verification using MST markers and pathogens

Step 3 Simulation of status quo and possible future scenarios using pathogens

\section{QMTRAsh}

\section{Risk Management Objective}

The case study addresses high level experts and water supply managers. The objective was to determine the needed pathogen reductions during riverbank filtration $(\mathrm{RBF})$ and final disinfection so that safe drinking water production can be guaranteed for the future. An approach integrating QMRA with hydrological process modelling that is driven by microbial source tracking (MST) and virus data is presented with the recently developed computational tool QMRAcatch (free download at: www.waterandhealth.at). 


\section{Location and setting}

The case study site is located at the Danube River in Austria and a river/floodplain area with important drinking water resources, serving also as important recreational area for the City of Vienna (300 thousand visitors per year). The study site can be regarded as a model area to study RBF systems in particular when conflicting land/ resource utilisations do exist.

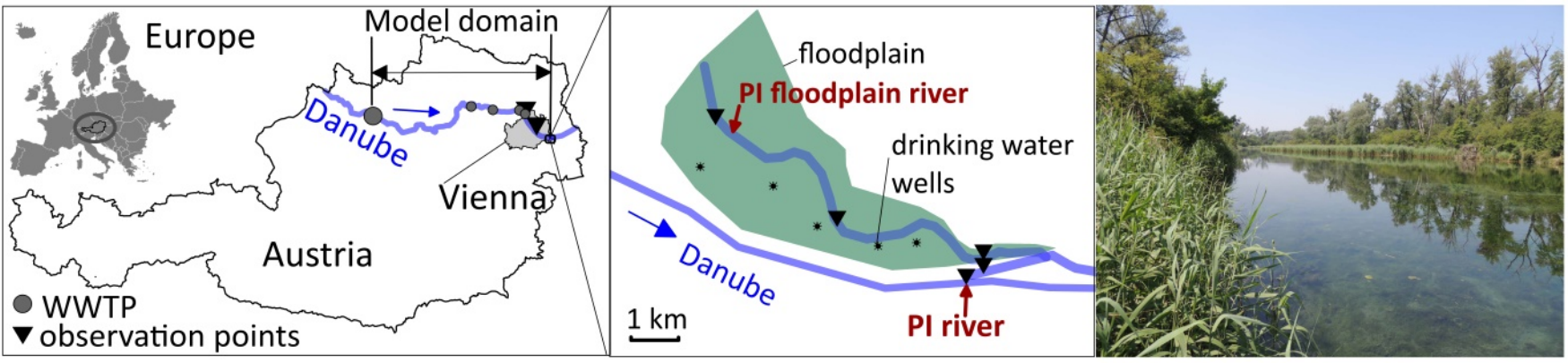

(Open access image from Derx et. al, 2016)

\section{Description of the System}

Several municipalities located upstream of the study site discharge biologically treated wastewater into the Danube River that include sporadic combined sewer overflows. The urban drinking water is produced from a well series after treatment by the RBF system and additional disinfection. Besides the impact from the Danube River, visitors and wildlife faecal pollution have potential impact on the microbiological water quality in the floodplain area.

\section{Outcome and recommendations}

The outcomes consist of the assessed faecal pollution burden and the needed virus reduction level by treatment of river source water to reach safe drinking water.

- Wastewater and pathogen emission risk scenarios for the studied site highlighted i) that further disinfection as an additional step after biological wastewater treatment would be the most powerful additional measure for environmental catchment protection, and ii) that the water treatment ensuring safe and sustainable drinking water production would require an $8 \log$ reduction of virus load during $\mathrm{RBF}$ and final disinfection to be robust against a high-pollution scenario (i.e. wastewater treatment failure combined with infection disease outbreak).

- The Water Safety Plan criteria can be fulfilled following the presented approach based on best available site-specific information including humanassociated MST and pathogen monitoring data. For applications in scarce-data areas stochastic modelling approaches are implemented which only require few information about the yearly river discharge and amount of rainfall.

- The Sanitation Safety Plan. The presented approach is also applicable for recreational water and irrigation.

\section{Introduction}

Riverbank filtration (RBF) is an important method for drinking water production worldwide. Upstream discharges of treated or untreated wastewater in densely populated areas or diffuse pollution from agricultural and wildlife wastes can cause a health burden from faecal pollution in rivers. Despite RBF is considered very effective in reducing microbes and viruses, changes in river flow rates or 
precipitation can cause diminished treatment efficiency (Derx et al., 2013). Pioneering ways of protecting water resources in the 21 st century, the World Health Organization (WHO) proposed the source-to-tap approach including infection risk assessments based on health targets (WHO, 2011). A basic requirement for this approach is to assess the source water quality based on multiparametric data sets and to develop catchment-specific fate and transport models. Modelling the status quo and future scenarios allows predicting impacts of future changes on water safety, e.g., urban population growth and changes in hydrological regimes induced by global warming. Possible strategies to mitigate these risks include further disinfection of biologically treated wastewater, the building of storm water reservoirs and green infrastructure, and an improved sanitation infrastructure.

This case study highlights a quantitative microbial risk assessment (QMRA) integrated with hydrological process modelling using QMRAcatch for drinking water resources located in a large river/floodplain area (Derx et al., 2016; Schijven et al., 2015). The presented approach addresses the sustainable development goal (SDG) 6.3 to prioritize on where and how to reduce the pollution. A source targeted monitoring campaign including microbial source tracking (MST) and enterovirus was conducted addressing SDG 6.5 to implement integrated water resource management at all levels. The monitoring data was used to inform and test the model for predicting levels of human faecal pollution in the river and the required treatment for safe drinking water production.

\section{Problem formulation}

The purpose of the QMRA was to determine robust reduction levels of pathogens for safe drinking water production. The criteria are here defined as the required virus log-reduction by RBF and subsequent disinfection to achieve the health-based target.

The scope was defined by:

- Hazard identification: Enterovirus measured in tissue culture after concentration and norovirus with concentrations in raw and treated wastewater and log-reduction by wastewater treatment assumed (Katayama et al., 2008; Lodder and Husman, 2005).

- Exposure pathway: Ingestion of drinking water by urban population produced by RBF system and subsequent disinfection.

- Health outcome: The required treatment was assessed to achieve the health-based target of less than one infection per 10000 persons per year.

\section{Exposure assessment}

1. Source: Enterovirus particles were present in the effluent of a wastewater treatment plant. Concentrations of these reference pathogens were determined by virus concentration and subsequent quantification in tissue culture on grab samples collected monthly from 2011 to $2012(n=16)$, (Chang et al., 1958; Walter and Rüdiger, 1981).
Norovirus concentrations in the effluent were assumed from the literature (Katayama et al., 2008; Lodder and Husman, 2005). For waterborne viruses, it is assumed that virus particles at low concentrations in water samples can be statistically described by the Poisson distribution. i.e., virus particles are assumed to be randomly distributed in the water sample (Derx et al., 2016).

2. Barriers/Controls: The treatment barriers consist of the RBF system and further disinfection. As controls, the HF183 MST marker and enterovirus concentrations in the Danube River $(\mathrm{n}=19 / 16)$ and in the floodplain river were measured $(n=17 / 6)$ from 2012 to 2013. The human-associated HF183 MST marker concentrations were determined by the TaqMan assay according to the procedure described by Green et al., (2014) with modifications for sample processing and DNA extraction described by Reischer et al., (2008). Concentrations of virus particles were determined by virus concentration and subsequent quantification in tissue culture. The QMRA integrated with hydrological process modelling was realized with the computational tool QMRAcatch (Schijven et al., 2015) free download link: www.waterandhealth.at). In QMRAcatch concentrations of health-related microbes/viruses in rivers and river/floodplain systems are simulated. Faecal indicator, MST-marker, and pathogen data are integrated with modelling to elucidate optimal catchment protection and treatment requirements (log-reductions) for health-related water safety management. QMRAcatch was set to match simulated with measured HF183 MST marker concentrations in the Danube River and the floodplain river (Derx et al., 2016). Concentrations in the Danube River were calibrated by adjusting the mixing degrees, the number of combined sewer overflows per year, and the HF183 MST marker concentrations in overflow water. Concentrations in the floodplain river were calibrated by adjusting the probability of visitors practicing open defecation (Phum) and the release rate (fraction of deposited numbers of HF183 MST markers in the floodplain released daily) (Derx et al., 2016). The HF183 MST marker concentrations in human faeces were further adjusted within the previously measured range (Farnleitner et al., 2014). After calibration the simulated and measured HF183 MST marker concentrations in the Danube and the floodplain river differed by less than $0.4 \log 10$ N/L. Simulated and measured enterovirus concentrations in the Danube River for 2012 and 2013 and in the floodplain river for 2013 were compared using the same settings as for the calibration. The observed and simulated enterovirus concentrations agreed with a difference of less than $0.6 \log 10 \mathrm{~N} / \mathrm{L}$ (Derx et al., 2016).

3. Intake: The dose is calculated from the pathogen concentrations in drinking water and the default value for drinking water consumption of 2 Liters per person and day (WHO, 2011). 


\section{Health effects assessment}

In order to determine the required virus removal by $\mathrm{RBF}$ and further disinfection for safe drinking water production, dose-response models were used. The dose response model for norovirus and enterovirus is the hypergeometric dose response model (Schijven et al., 2015; Teunis et al., 2008). It accounts for beta-distributed infectivity levels of the viruses and for Poisson-distributed virus particle numbers for the dose estimation. For enteroviruses, the dose response relationship is associated with the enumeration of infectious virus particles, as enumerated in the tissue culture. In the case of norovirus, the dose response model was developed based on PCR enumeration, which includes non-infectious virus particles (Teunis et al., 2008). Low and high pollution scenarios were defined by changing groups of model variables. The scenarios and the current situation were investigated for a dry year and a wet year with the calibrated model (Derx et al., 2016). In the simulations, the precipitation amounts and discharges from the Danube River and the floodplain river were taken from observational data in 2003 and 2002 because the lowest and highest mean annual discharges from the Danube River since 1996 were recorded in these years (Anonymous, 2014). The low pollution scenario was characterized by a low number of visitors contributing to human faecal pollution and a low probability of defecation (Phum) in the floodplain area. The high pollution scenario was characterized by a high number of visitors and a high Phum in the floodplain area (Derx et al., 2016). The runoff coefficient was set to 0.1 , and the ratio of evaporation to precipitation was set to 0.4 according to Merz and Bloschl, (2009). The viral release rate from faeces depends on the intensity of rainfall. This model variable was adjusted for an extremely dry year and an extremely wet year during the calibration (2012 and 2013), and then varied accordingly in the scenarios for the wet and dry years (Table 1), (Derx et al., 2016).

\section{Risk characterization}

For assessing the infection risk, the 95th-percentile enterovirus and norovirus concentrations in the Danube were calculated. The $\log 10$ reductions were then calculated to determine the virus removal necessary by RBF and further disinfection to safely produce drinking water at the point of water intake (Derx et al., 2016). For all scenarios, 106 Monte Carlo samples were processed. The drinking water wells take up a mixture of Danube River water, floodplain river water, and floodplain water with mixtures assumed for the dry and the wet years according to Taschke et al., (2014) (Table 1).

Table 1. Ranges of model variables for the scenarios for enterovirus and norovirus using QMRAcatch (Derx et al., 2016)

\begin{tabular}{|c|c|c|c|c|}
\hline Model Variable & Current Situation Wet/Dry Year & $\begin{array}{l}\text { Low Pollution } \\
\text { Wet/Dry Year }\end{array}$ & High Pollution Wet/Dry Year & Reference \\
\hline $\begin{array}{l}\text { Hydrology and } \\
\text { climate }\end{array}$ & \multicolumn{3}{|c|}{$\begin{array}{l}\text { Daily observed precipitation, water temperature, Danube and floodplain river discharge } \\
\text { from } 2002 / 2003^{\mathrm{a}}\end{array}$} & $\begin{array}{c}\text { Anonymous, } \\
(2016)\end{array}$ \\
\hline $\begin{array}{l}\text { Drinking water } \\
\text { sources (\%) }\end{array}$ & \multicolumn{3}{|c|}{ 80/60 Danube river, 20/20 floodplain river, 0/20 floodplain water } & $\begin{array}{l}\text { Taschke et } \\
\text { al., (2014) }\end{array}$ \\
\hline $\begin{array}{l}\text { Mean Log10 } \\
\text { reduction in } \\
\text { WWTPs }^{\mathrm{b}}\end{array}$ & 1 & 5 & 0 & $\begin{array}{c}\text { Gerrity et } \\
\text { al., (2012); } \\
\text { Owens et } \\
\text { al., (2000) }\end{array}$ \\
\hline $\begin{array}{l}\text { Visitor number } \\
\text { per day }\end{array}$ & 900 & $650^{\mathrm{c}}$ & $1700^{\mathrm{d}}$ & $\begin{array}{c}\text { Arnberger } \\
\text { et al., } \\
\text { (2009); } \\
\text { Eder and } \\
\text { Arnberger, } \\
(2012)\end{array}$ \\
\hline $\begin{array}{l}\text { Probability of } \\
\text { human open } \\
\text { defecation }\end{array}$ & $0.02 / 0.01$ & 0.0001 & 1.0 & - \\
\hline $\begin{array}{l}\text { Viral release } \\
\text { from feces } \\
\text { droplets per day }\end{array}$ & & $0.5 / 0.006$ & & $\begin{array}{c}\text { model } \\
\text { calibration } \\
\text { of this } \\
\text { paper }\end{array}$ \\
\hline Viral prevalence & 0.01 & 0.01 & 0.15 & $\begin{array}{l}\text { Zhang et } \\
\text { al., (2013) }\end{array}$ \\
\hline
\end{tabular}

${ }^{\text {a }}$ Selected based on the highest (wet) and lowest (dry) mean observed yearly discharge of the Danube

${ }^{\mathrm{b}}$ Wastewater treatment plants

${ }^{\mathrm{c} B i k e r s}$ and locals excluded

${ }^{\mathrm{d}}$ Full reported number 


\section{Risk management}

The simulations showed that $4.5 \log 10$ and $6.6 \log 10$ (95th percentiles) reductions in enterovirus and norovirus, respectively, must be achieved by RBF and disinfection to reach the health target (Derx et al., 2016). The results of the low and high pollution scenarios showed that the required virus removal ranges from 0 to $8 \log 10$. According to the simulations, the drinking water quality according to the health-based target can be achieved without further treatment of the river source water when biologically treated wastewater is further disinfected and measures are taken to prevent faecal pollution within the floodplain area. These outcomes indicate the great potential of protecting catchments from faecal pollution for minimizing the burden on water resources. This information can be used to support the future design of robust water supply systems and thus has implications for water suppliers and authorities.

\section{Evaluation of the QMRA}

The QMRA executed in this study was integrated with hydrological process modelling and informed by human MST marker, actual virus measurements from the Danube and dose-response curves for the health assessment. Uncertainty and variability of virus source concentrations and log-removal by wastewater treatment were taken into account by the Monte Carlo process using distributional assumptions. Further uncertainties may be involved as the distributional parameters for wastewater effluent were based on measured virus concentrations from grab samples. The river sample volumes were small in relation to the total river discharge which may induce data errors (Schmidt and Emelko, 2011). This error could be diminished by using improved sampling methods, e.g., proportional auto-sampling over a period of $24 \mathrm{~h}$ of wastewater effluent (Mayer et al., 2015) or large river sample volumes. Higher enteric virus reductions may be needed in case of an outbreak. Water managers thus need to be proactive, when planning in future investments in infrastructure for protecting water resource catchments. The outcomes of this study support this proactive planning by demonstrating the effectiveness of further disinfection in wastewater treatment or an improved sanitation infrastructure and the potential to derive robust treatment criteria.

\section{Acknowledgements}

This paper was supported by project 23900-B22 granted to AHF and the FWF (Vienna Doctoral Program on Water Resource Systems W1219-N22) and the GWRS project (Vienna Water) as part of the "(New) Danube-Lower Lobau Network Project" funded by the Government of Austria and Vienna, and the European Agricultural Fund for Rural Development (LE 07-13). This is a joint study effort of the ICC Water \& Health (www.waterandhealth.at).

This case study was derived from a research project, the results of which are published in the following journal article:

Derx, J., Schijven, J., Sommer, R., Zoufal-Hruza, C.M., van Driezum, I.H., Reischer, G., Ixenmaier, S., Kirschner, A., Frick, C., Husman, A.M.D., Farnleitner, A.H. and Blaschke, A.P. (2016) QMRAcatch: Human-Associated Fecal Pollution and Infection Risk Modeling for a River/Floodplain Environment. Journal of Environmental Quality 45(4), 1205-1214. doi: 10.2134/jeq2015.11.0560

This paper was supported by project 23900-B22 granted to AHF and FWF (Vienna Doctoral Program on Water Resource Systems W1219-N22) and the GWRS project (Vienna Water) as part of the "(New) Danube-Lower Lobau Network Project" funded by the Government of Austria and Vienna, and the European Agricultural Fund for Rural Development (LE 07-13). This is a joint study effort of the ICC Water \& Health (www.waterandhealth.at). 


\section{References}

Arnberger, A., Frey-Roos, F., Eder, R., Muralt, G., Nopp-Mayr, U., Tomek, H. et al. (2009). Ecological and social carrying capacities for peri-urban biosphere resources. Man \&amp; Biosphere-Programme of the Academy of Science. 135,.

Chang, S.L., Berg, G., Busch, K.A., Stevenson, R.E., Clarke, N.A. and Kabler, P.W. (1958). Application of the Most Probable Number Method for Estimating Concentrations of Animal Viruses by the Tissue Culture Technique. Virology. 6(1), pp. $27-42$.

Derx, J., Blaschke, A.P., Farnleitner, A.H., Pang, L., Bloschl, G. and Schijven, J.F. (2013). Effects of fluctuations in river water level on virus removal by bank filtration and aquifer passage - A scenario analysis. Journal of Contaminant Hydrology. 147, pp. 34-44.

Derx, J., Schijven, J., Sommer, R., Zoufal-Hruza, C.M., van Driezum, I.H., Reischer, G. et al. (2016). QMRAcatch: HumanAssociated Fecal Pollution and Infection Risk Modeling for a River/Floodplain Environment. Journal of Environmental Quality. 45, pp. 1205-1214.

Farnleitner, A., Derx, J., Frick, C., Reiner, P., Savio, D., Zoufal-Hruza, C. et al. (2014). Water connection (New) Danube. Lower Lobau (Nationalpark Donauauen), Water quality report for microbiology/water hygiene. Municipal Department MA45, Vienna Water. Vienna, Austria.

Gerrity, D., Gamage, S., Jones, D., Korshin, G.V., Lee, Y., Pisarenko, A. et al. (2012). Development of surrogate correlation models to predict trace organic contaminant oxidation and microbial inactivation during ozonation. Water Research. 46, pp. 6257-6272.

Green, H.C., Haugland, R.A., Varma, M., Millen, H.T., Borchardt, M.A., Field, K.G. et al. (2014). Improved HF183 Quantitative Real-Time PCR Assay for Characterization of Human Fecal Pollution in Ambient Surface Water Samples. Applied and Environmental Microbiology. 80, pp. 3086-3094.

Katayama, H., Haramoto, E., Oguma, K., Yamashita, H., Tajima, A., Nakajima, H. et al. (2008). One-year monthly quantitative survey of noroviruses, enteroviruses, and adenoviruses in wastewater collected from six plants in Japan. Water Research. 42, pp. 1441-1448.

Lodder, W.J. and Husman, A.M.D. (2005). Presence of noroviruses and other enteric viruses in sewage and surface waters in The Netherlands. Applied and Environmental Microbiology. 71, pp. 1453-1461.

Mayer, R.E., Vierheilig, J., Egle, L., Reischer, G.H., Saracevic, E., Mach, R.L. et al. (2015). Automated Sampling Procedures Supported by High Persistence of Bacterial Fecal Indicators and Bacteroidetes Genetic Microbial Source Tracking Markers in Municipal Wastewater during Short-Term Storage at 5 degrees C. Applied and Environmental Microbiology. 81, pp. 5134-5143.

Merz, R. and Bloschl, G. (2009). A regional analysis of event runoff coefficients with respect to climate and catchment characteristics in Austria. Water Resources Research. 45,.

Owens, J.H., Miltner, R.J., Rice, E.W., Johnson, C.H., Dahling, D.R., Schaefer, F.W. et al. (2000). Pilot-scale ozone inactivation of Cryptosporidium and other microorganisms in natural water. Ozone-Science and Engineering. 22, pp. 501-517.

Reischer, G.H., Haider, J.M., Sommer, R., Stadler, H., Keiblinger, K.M., Hornek, R. et al. (2008). Quantitative microbial faecal source tracking with sampling guided by hydrological catchment dynamics. Environmental Microbiology. 10, pp. 2598-2608.

Schijven, J., Derx, J., Husman, A.M.D., Blaschke, A.P. and Farnleitner, A.H. (2015). QMRAcatch: Microbial Quality Simulation of Water Resources including Infection Risk Assessment. Journal of Environmental Quality. 44, pp. 1491-1502.

Schmidt, P.J. and Emelko, M.B. (2011). QMRA and decision-making: Are we handling measurement errors associated with pathogen concentration data correctly?. Water Research. 45, pp. 427-438. 
Taschke, R., Blaschke, A.P., Gabriel, H. and Mayr, E. (2014). Water connection (New) Danube - Lower Lobau (Nationalpark Donauauen), Water Quantity Report for Groundwater. Municipial Department MA45 - Vienna Waters. Vienna, Austria.

Teunis, P.F.M., Moe, C.L., Liu, P., Miller, S.E., Lindesmith, L., Baric, R.S. et al. (2008). Norwalk virus: How infectious is it?. Journal of Medical Virology. 80, pp. 1468-1476.

Walter, R. and Rüdiger, S. (1981). Ein Zweistufenverfahren zur Virusanreicherung aus Lösungen mit geringem Virustiter. Journal of hygiene, epidemiology, microbiology, and immunology. 25, pp. 71-81.

World Health Organization (WHO) (2011). Guidelines for drinking-water quality. 4th edition World Health Organization (WHO). Geneva, Switzerland. 